\title{
Metabolic Engineering: New Era in Pharmaceuticals
}

\author{
Singh PP,Kumar A,Singh R,Vandana,Singh PK, Pandey KD* \\ Centre of Advance study in Botany, Banaras Hindu University, India
}

Submission: March 30, 2017; Published: June 06, 2017

*Corresponding author: Kapil Deo Pandey, Centre of Advance Study in Botany, Institute of Science, Banaras Hindu University, India, Tel: +91-9450547298; Fax: +91542-6701124; Email: kdpandey2005@gmail.com

\begin{abstract}
Currently pharmaceutical metabolic engineering is playing an important role in production and designing of drugs as well as precursors of drug. Metabolic engineering is the refinement of industrial organisms by studying the physiological consequences of particular genetic changes in microorganisms, plants, and animals, and also devising the mathematical and computational methods to understand connections between genes and cell function. Upgradation of metabolic engineering by consolidate use of global technologies of systems biology, capabilities of synthetic biology, and evolutionary engineering enables optimal design of a microorganism for production of natural and synthetic drugs in a better optimized and multiplexed way on a genome scale, with reduced time and effort.
\end{abstract}

Keywords: Metabolic engineering; Systems biology; Synthetic biology; Pharmaceuticals

\section{Introduction}

Natural products are a prime source for drug industry as their products are often used as drug or drug precursors. But, their extraction and synthesis in large amount are eminently difficult and a major challenge till date. So, for the production of steadily more amount of these drugs and drug precursors, researchers focused on the new metabolic engineering strategies [1]. Metabolic engineering can be defined as purposeful refitting of cellular metabolic networks in living cells to engender the desirable product with superior yield and productivity using recombinant DNA and other molecular biology techniques [2].

In this structure, it uses the upshots of high-throughput techniques for deciphering genomes, transcriptomes, proteomes, metabolomes and fluxomes, together with computational tools [3]. The main concerns during the metabolic engineering are the investigations undertaken to produce chemicals of commercial interests, efficiently and abundantly using appropriate microorganisms [4]. It is also used as a key enabling technology for transforming microorganisms into efficient cell factories as growing concerns over limited fossil resources and associated environmental problems, which impel the development of sustainable processes for the production of chemicals from renewable resources. Metabolic engineering significantly contributed in enhanced production of various value-added and commodity chemicals and materials from renewable resources in the past two decades.
In the drug designing, natural products are prime sources. As per previous reports between 1981 and 2014, 51\% drugs were based on natural products whereas $49 \%$ were synthetic as approved by pharmaceuticals. Pharmaceuticals derived from natural products are semi-synthesized, starting with a microbially produced or plant-extracted natural product, which is then chemically modified to improve therapeutic properties including absorption, distribution, metabolism, excretion, and toxicity [5]. All This is typically achieved by establishing new metabolic pathways leading to the product formation, and enforcing or removing the existing metabolic pathways toward enhanced product formation. Recently in system biology and synthetic biology, certain advances has been allowed us to perform metabolic engineering at the whole cell level for the optimal design of a microorganism for the efficient production of drugs and drug precursors. Microbial production of strategically modified drugs has the capability to accelerate the production and reduce the cost of FDA-approved drugs [1].

In spite of microbial production of diverse chemicals and materials from renewable resources, there is a complication i.e., efficiency of microbial metabolism has not been as much as desired by humankind from the microbes, isolated from nature. Metabolic engineering plays a great role in converting these reluctant biofactories into highly efficient machines capable of generating huge quantities of a molecule of interest. In addition, 
recent advances in three emerging fields, systems biology, synthetic biology, and evolutionary engineering have allowed us to perform metabolic engineering more systematically and globally.

Systems biology aims at unravelling the underlying principles of biological systems through profiling the whole cellular characteristics together with computational methods. It provide genome-wide information that facilitates metabolic engineering at various phases by predicting gene targets and identifying novel biological entities to be manipulated throughout the whole cellular network that contribute to enhanced production of chemicals and materials [6]. While Synthetic biology focuses on creating novel biologically functional parts, modules and systems by consolidate use of molecular biology with mathematical methodologies [7]. It develops to redirect metabolic pathways to produce novel metabolites and various other amendments. Evolutionary engineering tune and adapt the expressions of multiple genes accordingly the natural selection rules for the desired cellular properties alone with metabolic engineering [8] (Figure 1).

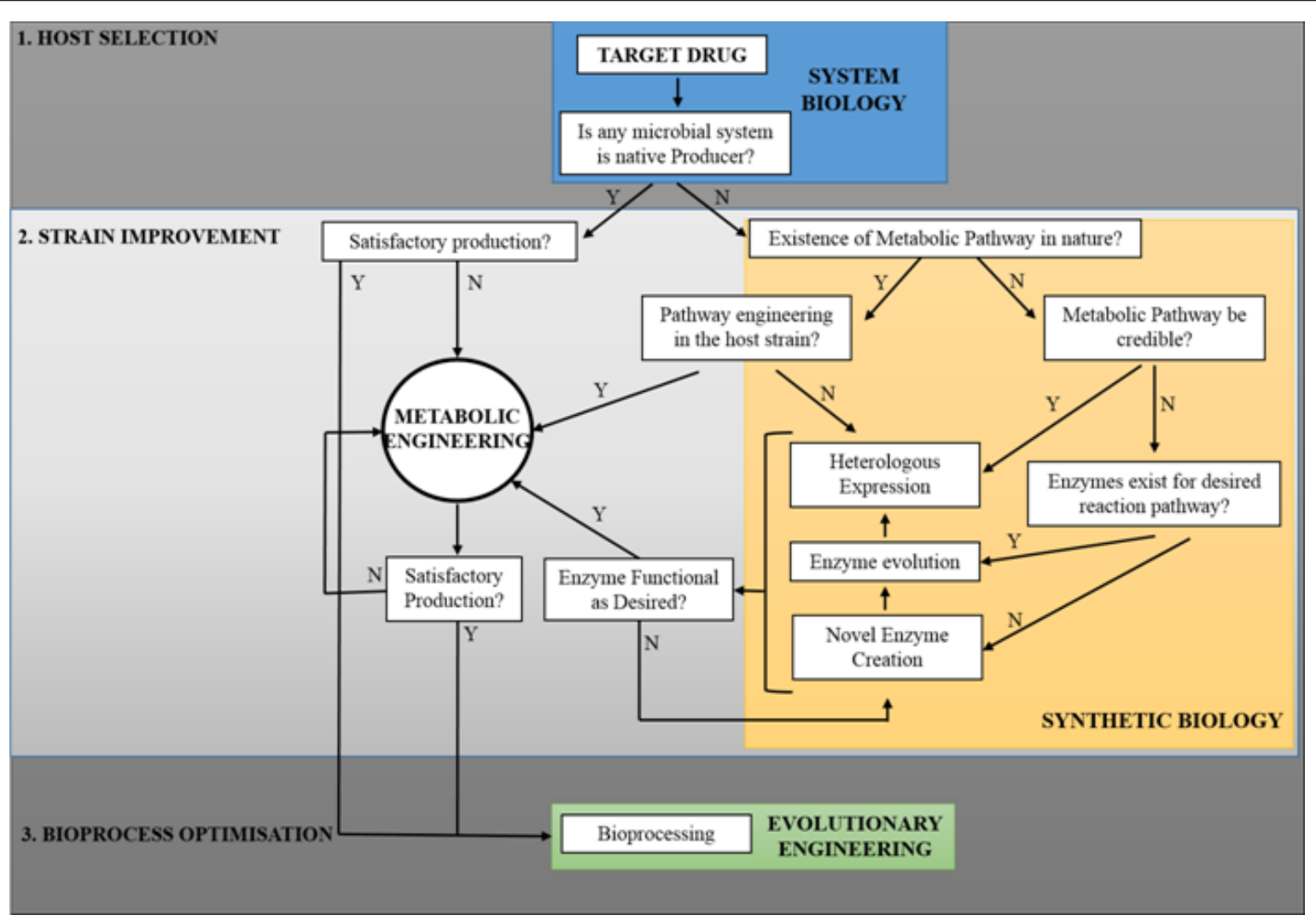

Figure 1: Several Metabolic Engineering Pathways along all of its tolls and steps ( $\mathrm{Y}=\mathrm{Yes} ; \mathrm{N}=\mathrm{No}$ ).

There are sundry exemplar cases of applying metabolic engineering for the development of microbial strains producing drugs and drug precursors that have been reported. Metabolic engineering of microbes for the production of artemisinic acid (precursor of artemisinin that is an effective drug against malaria-causing Plasmodium sp.) [9], daptomycin analog A21978C which serve as non-ribosomal peptide produced in Streptomyces roseosporus, and is effective for treating skin infection caused by Gram-positive pathogens [10] etc.

\section{Future Perspective}

Metabolic engineering has enabled sophisticated engineering of various microorganisms for the efficient production of various metabolites. Currently, it will play important role in developing new drugs and drug precursors, including secondary metabolites found in living organisms, because of complex structure and chirality of the metabolites which are difficult to synthesize chemically. It can also help in creation of library of compounds which may be used for the discovery and designing of new drugs. Metabolic engineering along with molecular biology and methods like promoter engineering and transcription factors helps in increased productivity. Whereas omics techniques and the genome scale in silico simulations will be highly employed for regulatory and signalling networks for various prospects which help in prediction of target genes and pathways which need to be engineered. It is expected that microbial metabolic engineering will become an essential platform for the development and production of drugs in the near future. 


\section{Acknowledgement}

Authors are thankful to Head, Department of Botany, Banaras Hindu University for providing lab facilities.

\section{References}

1. Lee SY, Kim HU, Park JH, Park JM, Kim TY (2009) Metabolic engineering of microorganisms: general strategies and drug production. Drug Discov Today 14(1-2): 78-88.

2. Bailey JE (1991) Towards a science of metabolic engineering. Science 252(5013): 1668-1676.

3. Lee JW, Na D, Park JM, Lee J, Choi S, et al. (2012) Systems metabolic engineering of microorganisms for natural and non-natural chemicals. Nature chemical biology 8(6): 536-546.

4. Ikeda M, Katsumata R (1992) Metabolic engineering to produce tyrosine or phenylalanine in a tryptophan-producing Corynebacterium glutamicum strain. Appl environ microbiol 58(3): 781-785.
5. Ehrenworth AM, Peralta-Yahya P (2017) Accelerating the semisynthesis of alkaloid-based drugs through metabolic engineering. Nature Chemical Biology 13(3): 249-258.

6. Park JH, Lee SY, Kim TY, Kim HU (2008) Application of systems biology for bioprocess development. Trends in biotechnology 26(8): 404-12.

7. Picataggio S (2009) Potential impact of synthetic biology on the development of microbial systems for the production of renewable fuels and chemicals. Curr Opin Biotechnol 20(3): 325-329.

8. Lee JW, Kim TY, Jang YS, Choi S, Lee SY (2011) Systems metabolic engineering for chemicals and materials. Trends in biotechnology 29(8): 370-378.

9. Ro DK, Paradise EM, Ouellet M, Fisher KJ, Newman KL, et al. (2006) Production of the antimalarial drug precursor artemisinic acid in engineered yeast. Nature 440(7086): 940-943.

10. Penn J, Li X, Whiting A, Latif M, Gibson T, et al. (2005) Heterologous production of daptomycin in Streptomyces lividans. J Ind Microbiol Biotechnol 33(2): 121-128.

\section{Your next submission with Juniper Publishers} will reach you the below assets

- Quality Editorial service

- Swift Peer Review

- Reprints availability

- E-prints Service

- Manuscript Podcast for convenient understanding

- Global attainment for your research

- Manuscript accessibility in different formats

( Pdf, E-pub, Full Text, Audio)

- Unceasing customer service

Track the below URL for one-step submission https://juniperpublishers.com/online-submission.php 